\title{
An Analysis on the Use of Video Materials in College English Teaching in China
}

\author{
Zhaogang Wang ${ }^{1}$ \\ ${ }^{1}$ School of International Business Communication, Dongbei University of Finance and Economics, Dalian, China \\ Correspondence: 217, Jian Shan Street, School of Business Communication, Dongbei University of Finance and \\ Economics, Dalian, China 116025. Tel: 86-411-84743192. E-mail: fromfrank@139.com
}

Received: August 5, 2014

Accepted: August 20, 2014 Online Published: September 26, 2014

doi:10.5430/ijelt.v2n1p23

URL: http://dx.doi.org/10.5430/ijelt.v2n1p23

\begin{abstract}
There is a wide use of video materials in EFL teaching for non-English majors in Chinese universities and colleges. However due to the weak theoretical foundation for this practice, there are numerous delicate issues in classroom practice which entails careful thoughts and reflections. This paper first attempts to explore the goals of using video material in EFL classrooms and the advantages of video materials in EFL teaching, on the basis of which proposes a framework of teaching principles, strategies and tips on specific techniques of using video materials in the hope of facilitating EFL teaching for non-English majors.
\end{abstract}

Keywords: video material, EFL teaching, teaching strategies

\section{Introduction}

With the rapid development of educational technology and emphasis on English listening and speaking skills in China, English teaching for non-English majors in Chinese universities and colleges has been expanding continuously since 1978. As one of the main sources of authentic language learning materials, English videos such as movies and soap operas are widely used in EFL listening and speaking classrooms. Although the effects of audio and visual aids on language learning are very complex and researchers as well as language teachers cannot agree with each other on the specific processes and details of how visual aids can facilitate language learning (Baltova, 1994; Canning-Wilson, C., 2000), there is a unanimous agreement that authentic English videos as audio and visual aids have positive effects on the enhancement of EFL learners' listening and speaking skills. However, as an independent course, teaching English through videos does not have well-established methodology and recognized patterns. As a result, teachers do not have clear goals in mind in their classroom activities and their attentions are often not focused. Classroom activities and teaching methods are often monotonous, random and improvised, which frequently gives rise to the inefficiency in the use of video materials in EFL classrooms.

One of the approaches to these issues is to hammer out a pedagogical framework for teaching English with video materials to guide teachers' activities. On the basis of my own classroom practice, this paper examines the key issues in the teaching of English with video materials. The second part presents the goals of teaching English with video materials. The third part lists the advantages of video materials in English teaching. The fourth part offers some suggestions on the use of video materials in English teaching. The final part summarizes the entire paper and proposes directions for further studies.

\section{The Goals of Teaching English with Video Materials}

The effects of teaching English with video materials on students are in many cases not well matched with the efforts that teachers and students have made because teachers do not have clear goals in mind in classroom activities. It is necessary for language teachers to keep clear goals in mind in the classroom when they use video materials because they must prepare their teaching plans and implement them in reality in order to achieve their goals. Generally speaking, language teachers could set up three goals for their teaching with video materials.

The first and fundamental goal is to facilitate the development of EFL learners' language skills and in particular their 
listening and speaking skills. Video materials provide visual aids for the listening materials that EFL learners are exposed to. When they are practicing their listening skills, learners often find it difficult to hold their attention long enough once they are exposed to long conversations or passages without visual aids. Videos can provide much more information for listeners and can keep them attention focused on the aural material. On the other hand, authentic video materials can create more realistic language learning environment and stimulate EFL learners' interest in English learning and enhance their comprehensive linguistic competence. Language learning theories state that the process of language learning includes three key parts: language input (reading and listening), assimilation (internal processing and memorization) and language output (speaking, writing and translation). The process of viewing video materials in the classroom is a combination of language input and assimilation. Language learners can improve their listening and speaking skills consciously and subconsciously in viewing video materials and talking about them after the films are over. Students can also assimilate the linguistic and cultural information contained in the video materials. A rich variety of classroom and after-class activities after viewing the video materials provide excellent opportunities for students to practice their language output.

The second and intermediate goal of teaching English with video materials is to cultivate students' competence of intercultural communications. Video materials such as Hollywood movies and soap operas carry heavy social and cultural background information about English-speaking countries. Since different languages embody the differences of countries in such aspects as social customs, natural environment, tradition and national ethos, it is impossible to learn a foreign language without a good understanding of its cultural background. English movies provide students with direct, vivid and realistic materials to understand the culture and society of English speaking countries because they can reveal differences between Chinese and western cultures through such aspects as the way in which stories are told, how stories are planned and the relationship of characters. If we want to understand the profound implications of carefully selected English video materials, we must first study western culture, history, tradition, social customs and problems. Accordingly, we also have to reflect about the differences between Chinese values and western values, on the basis of which we would be able to understand the differences of Chinese and westerners in the fundamental way of thinking. In the end students would be able to use the English language appropriately in intercultural communications.

Let us take the movie Princess Diaries as an example. In the movie, the queen made very strict rules for her disobedient granddaughter to show her nobility and status. Students can have a very good understanding of complicated formalities of European aristocracy through this movie. Another movie Sense and sensibility tells students how unfair the law was for women in the seventeenth century because they had no right to inherit their father's property even though they had charming beauty and good-natured personalities. Although such laws do not exist anymore, students can have a glimpse of English history and culture of that period. Moreover since sense and sensibility is itself an English classic students will have direct understanding of the basic story without having to read the novel and it is also a good visual aid for some avid students who want to read the English novel.

The third and advanced goal of English teaching with video materials is to cultivate students' aesthetic values and ability to appreciate English videos of artistic values. Teaching English with video materials should not be confined to giving students opportunities to see English films. After a film is over, students still have aesthetic impressions of the film lingering in their minds, which is the best time for teachers to encourage students to deconstruct, decode and savor the film, on the basis of which students should be encouraged to have in-depth thinking and critical reviews of the film. Therefore, students could benefit the most from their efforts of learning English with video materials.

Motion pictures as an art have a very complicated school of theories. Teaching English with video materials should be different from courses on theories of motion pictures because the goal of learning English with videos and movies is not to study theories on movies and videos but to use film theories to analyze and appreciate English video materials. Due to the limitations of time and students' receptivity, teachers could select some fundamental theories and principles on motion pictures in their lectures. In terms of aesthetic appreciation, before playing a film teachers could introduce related background to students and analyze the story such as the theme of the story, genre of the story, main characters, and style of narration. Teachers could also tell students about the techniques of the film such as pictures, scenes, acoustics, and montage. Having some knowledge about the art of motion pictures will prompt students to improve their aesthetics as well as their English skills and competence of intercultural communication.

\section{The Advantages of Video Materials in English Teaching}

Video materials have plenty of advantages in English teaching which could be embodied in the following aspect: 


\subsection{Teaching English with Video Materials Can Stimulate Students' Autonomy and Proactivity.}

When teachers bring video materials into their English classrooms, students can directly acquire a great amount of cultural background information and emotional attitudes about the learning materials. Therefore they could employ their autonomy in language learning. While viewing the video materials, students can put themselves in the vivid atmosphere created by the video materials and understand the pragmatics of the language used by the characters. Compared with traditional English teaching, such courses truly put into practice the student-centered teaching strategies.

3.2 Video Materials Enrich Classroom Activities, Motivate Students' Passion for English Learning and Help to Hold Their Attention in the Classrooms.

Teaching English with video materials have advantages that other teaching methods do not have because video materials have the sound effects, vivid scenes and dialogues between characters backed up by visual aids. English video materials can provide teachers with more choices in classroom activities and avoid the boredom and monotony of traditional English teaching materials. As a result, students will be able to improve their efficiency of language learning tremendously and teachers will also be able to achieve their goals of English teaching.

3.3 English Video Materials Selected for Language Teaching Are Mostly Depictions of Realistic Circumstances in Life.

Students can see how language is used in real life which is very different from the traditional English teaching materials. For example, the dialogues and voice-overs in the classic movie Forrest Gump provide authentic language input and motivate students to practice their spoken English. Many colloquial expressions and patterns in movies are very difficult to understand and grasp with the help of the visual aids. Listening to different varieties of accents help students strengthen their listening skills and improve their pronunciation and intonation effectively.

3.4 Teaching English with Video Materials Provide Students with Direct Access to a Taste of Western Culture, which Can Complement Traditional English Teaching which does not Pay Enough Attention to the Development of Students' Intercultural Communication Skills.

Language is an integral part of culture and it plays a vital role in the development of students' cultural awareness. Learning English does not only mean the acquisition of such linguistic knowledge as pronunciation, grammar, vocabulary and idiomatic expressions but also means learning how to think like westerners which means English learners have to understand the values, social customs and habits of westerners in order to reach near-native English proficiency. Learning English cannot be separated from the study of the culture of English speaking countries. However, for a long time it is ignored to a large extent in college English teaching in China. Although many students have mastered the four basic language skills of listening, speaking, reading and writing, they in many cases cannot communicate with native English speakers properly because of insufficient knowledge of the cultural and social background of English speaking countries. Because English teaching in China is to a large degree intended for test preparation of one kind or another, teachers pay most of their attention to linguistic forms but ignore the practical use of linguistic forms. Teaching English with video materials can tackle such problems because it combines English learning with the acquisition of social and cultural knowledge and in the end it will enhance students' cognitive competence in English and cultivate English way of thinking.

\section{The Issues and Strategies of Using Video Material in English Teaching}

In any educational activities, teachers must be able to supervise students' learning process effectively in order to realize their teaching goals. Teaching English with video materials is no exception. In order to achieve the systematic and goal-oriented teaching with video materials, teachers must plan their strategies of teaching carefully,

\subsection{The Selection of Video Materials}

First of all, teachers must be careful with the content of video materials such as Hollywood movies and soap operas. Driven by voracious commercial interests, many producers try to attract viewers with movies fraught with violence and adult content. Teachers should not include such video materials in their class. In addition, teachers should not choose movies that are too obscure for students to understand. Movies and soap operas that reflect everyday life and culture of different periods and regions of English speaking countries are very good learning materials. Video materials that tell stories of historic figures and events are very informative and interesting materials too. Musicals and animations could also be very exciting and relaxing choices. In general, in order to attract students' attention, teachers should choose video materials with simple and morally correct stories, realistic characters and conversations 
that are brief and clear.

Secondly, because teachers are helping students with their English in the classroom they must scrutinize the language of video materials used for teaching in terms of pronunciation, intonation, authenticity, and imitability. Non-standard English used by characters in videos has negative impacts on students' acquisition of the language. Some nasty language such as four-letter words could be very bad influence for students and if teachers do not give them proper explanations students could make very pragmatic mistakes when they use these words in conversations with native speakers of English.

Thirdly, teachers should control the difficulty of video materials they choose because they have to take into consideration the actual level of students' English. As a rule of thumb, teachers should select movies that will interest students and match their English level of proficiency. Video materials that are far higher or lower than their English proficiency will not hold students' attention. Sometimes the use of subtitles could help students understand video materials.

Finally, teachers must keep in mind that they should not play the movies for students only because video materials like movies are only used to help students to learn English language and culture. Teachers should always keep the three goals of teaching English with video materials.

\subsection{Teachers Should Design Many Varieties of Classroom Activities to Take Full Advantage of Video Materials in the Classroom.}

Due to the variability among students with regard to their linguistic and cognitive competence, teachers may find it difficult to carry out in-depth discussions on topics of video materials. In order to avoid the problem, teachers should tell students what to prepare for the topics of discussion beforehand. Students can be divided into several groups and each group should include students of both higher and lower English proficiency. Every member in each group should be given specific tasks and they should work together to search and study relevant reading materials before viewing an English video. Finally they have to collect and summarize all materials to prepare for discussions in the classroom. Teachers can ask students to look for introductions to movie stories, views of movie critics, biographies of producers or stars, social and cultural background of a movie or even a simple anatomy of a movie. All of these materials can be accessed on the internet. With so much pre-reading about a movie, students can not only be well-prepared for classroom activities before and after viewing a movie but also can increase their vocabulary and reading comprehension tremendously.

Teachers should not play a movie without giving students any help in the process. They are organizers and facilitators of classroom activities. Teachers could use many techniques in the classroom such as pausing a movie, playing back some episodes several times, dividing an entire movie into several parts, and turning off the sound or pictures in the teaching process. When students view a scene related to a main topic for classroom discussion, teachers could pause the movie and ask students to do some language exercises such as imitation, repetition, dictation, dubbing, and role-play. Meanwhile, teachers could ask some questions based on the scene. As a result, students will pay attention to the details of relevant episodes and understand the plots much better. For students what movie stars say is much more impressive than texts in books so they are more willing to imitate the actors and practice their spoken English. Teachers should take such opportunities to ask students to improve their linguistic instincts. On the other hand, teachers could not pause too many times during the movie-viewing process, because too many interruptions will kill students' patience and passion in learning with video materials. Therefore teachers have to design the whole teaching process carefully and maintain a good balance between giving students opportunities to enjoy and learn at the same time.

A large variety of exercises following video materials will help students to have an in-depth understanding of these video materials. Teachers could help cultivate students' lateral thinking skills by having discussions on the cultural background and philosophical ideas of the video materials to check students' sensitivity of the details in the video materials the effects of the pre-class activities and their spoken English. After these discussions, teachers could summarize the key points of students' presentations to help them better understand what is discussed.

\subsection{Teachers Should Combine the Appreciation and Anatomy of Video Materials.}

After viewing an English movie or a soap opera, teachers should guide their students to have in-depth, higher level aesthetic discussions and reviews. Therefore teachers should give students some basic knowledge on movie theories, because without a framework of movie theories students cannot go from the stage of viewing movies passively to the stage of appreciating and analyzing the movies actively. On the other hand, it must be kept in mind that if teachers lecture on pure movie theories without examples of movie clips students will be so bored that they could not focus 
on teachers' lectures at all. As a result teachers cannot achieve the goal that they have set up before going into the classroom. A more appropriate method is to allow students to see a movie and then give them some theoretical principles embodied in the movie. After that teachers could ask students to review the movie and analyze the application of the theoretical principles used in the movie. For example, there are seven basic types of stories in most narrative movies: overcoming the monster, the quest, the voyage and return, rags to riches, and the rebirth, as well as comedy and tragedy (Booker C., 2006). Teachers could ask students to analyze and write essays about movies like Casablanca and Brave Heart about how these films use one or more basic types of plots. Students must write clearly to support their points with evidences they could find in these movies.

\section{Conclusions}

Video materials such as movies and soap operas contain enormous amount of information about the social and cultural background of English speaking countries. They not only provide students with authentic language material and environment of real communications but also have great aesthetic value. Therefore if teachers have clear goals in mind and plan the teaching process and strategies carefully, video materials can improve students' comprehensive linguistic competence, their cultural awareness and their aesthetic appreciation skills.

\section{References}

Allen, M. (1990). Teaching English with Video. London: Longman.

Arcario, P. (1992). Criteria for selecting video materials in Stempleski S., \& Arcario P. (Eds.), Video in second language teaching: Using, selecting and producing video for the classroom (pp. 109-121). Alexandria, VA: TESOL.

Arthur, P. (1999). Why use video? A teacher's perspective. Visual Support in English Language Teaching, 2(4), 4.

Baltova, I. (1994). Impact of video on the comprehension skills of core French students. Canadian Modern Language Review, 50(3), 506-531.

Booker C. (2006). The Seven Basic Plots: Why We Tell Stories. New York: Bloomsbury Academic.

Bouman, L. (1990). Veni, Video, Vici: Video in Language Teaching. Journal of English Teaching Forum, 18(2), 1-8.

Canning-Wilson, C., (2000). Role of Video in the F/SL Classroom, 69-76. In S. Riley, S Troudi, \& C. Coombe (Ed.), Teaching, Learning and Technology, TESOL Arabia 1999 Conference Proceedings, TESOL Arabia 1999 Conference March 8-10, 1999.

Canning, C. (1997).Theoretical use of Visuals. In Canning, C., \& Koester, J., Illustrated Visual Aids for Academic English, 1(1), 2-4

Chen Luoyu. (2008). A Literature Survey on English Videos and College English Teaching. Journal of Wuhan Institute of Science \& Technology, 7, 66-69.

Costanzo, W. V. (2004). Great Films and How to Teach Them. Illinois: National Council of Teachers of English (NCTE).

Dai Jin. (2005). Video Captions and Foreign Language Teaching. Computer-Assisted Foreign Language Education, 6 , $18-22$.

Golden, J. (1968). Reading in the Dark: Using Film as a Tool in the English Classroom. Illinois: National Council of Teachers of English (NCTE).

Gorder, L. M. (2008). A study of teacher perceptions of instructional technology integration in the classroom. Delta Pi Epsilon Journal, 50(2), 63-76.

Hemei, J. (1997). Teaching with Video in an English Class. Journal of English Teaching Forum, 35(2), 45-47.

Herron, C, Hanley, J., \& S. Cole. (1995). A comparison study of two advance organizers for introducing beginning foreign language students to video. Modern Language Journal, 79(3), 387-394.

Herron, C. (1994). An investigation of the effectiveness of using an advance organizer to introduce video in the 
foreign language classroom. Modern Language Journal, 78, 190-198.

Holden, W. (2000). Making the most of movies: keeping film response journals. Modern English Teacher, 9(2).

Joshi, B. (1995). The role of visual communication in teaching English. The Progress of Education, 9, 266-268.

Lan R., \& Zhao Y. (2008). On the selection of video materials in college English teaching. Journal of Liaoning Public Administration College, 7, 172-173.

Li Y. (2006). The use of English films in college English teaching. Movie critical Review, 22, 69- 71.

Lin, Li-Yun. (2000). Motivational and effective film activities for the language lab class. Proceedings of the seventeenth conference on English teaching and learning in the ROC. 497-505.

Longergan, J. (1984). Video in Language Teaching. Cambridge: Cambridge University Press.

Lynn A. (2005). Appreciating Cinema. Beijing: Foreign Language Teaching and Research Press.

Malcolm David Keene. (2006). Viewing Video and DVD in the EFL Classroom. Bunkyo Gakuin University Journal, $8(1), 217-234$.

Maniruzzaman, M., \& M. M. Rahman. (2008). The use of audio aids in the EFL Class at the tertiary level: A plus or a minus? Daffodil University International Journal of Business and Economics, 3(1), 121-137.

Mueller, G. (1980). Visual Contextual Clues and Listening Comprehension: An experiment. Modern Language Journal, 64, 335-340.

Omaggio, A. (1979).Pictures and Second Language Comprehension: Do They Help? Foreign Language Annals, 12, 107-116.

Özkan, B. (2002). The Use of Video Cases in Teacher Education, Turkish Online Journal of English Teaching, 1(1), $12-18$

Sherman J. (2003). Using Authentic Video in the Language Classroom. Cambridge: Cambridge University Press.

Stempleski, S., \& Arcario, P. (1992). Video in Second Language Teaching: Using, Selecting, and Producing video for the Classroom. Teachers of English to Speakers of Other Languages (TESOL): Alexandria, Virginia.

Zhang Xinyuan. (2008). On Appreciation of Teaching English Movie. Journal of Anhui University of Technology (Social Sciences), 24(3), 47-49.

Williamson, J. A., \& Vincent, J. C. (1999). Film is Content. A Study Guide for the Advanced ESL Classroom. Ann Arbor: The University of Michigan Press.

Willis, J. (1983). 101 Ways to Use Video. In: McGovern, J., Video Applications in English Language Teaching. English Language Teaching Documents. Oxford: Pergamon. 